\title{
Originals
}

\section{Blood Glucose and Plasma Insulin Responses to Various Carbohydrates in Type 2 (Non-Insulin-Dependent) Diabetes}

\author{
C. Ionescu-Tîrgovişte, E. Popa, E. Sîntu, N. Mihalache, D. Cheţa and I. Mincu \\ Clinic of Nutrition and Metabolic Diseases, Bucharest, Romania
}

\begin{abstract}
Summary. The blood glucose and plasma insulin responses to some simple carbohydrates (glucose, fructose, lactose) and some complex ones (apples, potatoes, bread, rice, carrots and honey) were studied in 32 Type 2 (non-insulin-dependent) diabetic patients. Blood glucose and plasma insulin were measured at zero time and then at $15,30,60,90$ and $120 \mathrm{~min}$ after ingestion of $25 \mathrm{~g}$ glucose, fructose or lactose, or $30 \mathrm{~g}$ honey, $50 \mathrm{~g}$ white bread, $125 \mathrm{~g}$ white rice or potatoes, $150 \mathrm{~g}$ apples or $260 \mathrm{~g}$ carrots. Maximum blood glucose and plasma insulin responses were recorded $60 \mathrm{~min}$ after ingestion of each test meal. At this time the increases in blood glucose and in plas-
\end{abstract}

ma insulin were significantly higher after the more refined carbohydrates (glucose, fructose and lactose) than after the more complex ones (apples, potatoes, rice, carrots and honey, $-p<0.01$ ). Counting the blood glucose increase after glucose as $100 \%$, the corresponding increases in glycaemia for other carbohydrates were: fructose, $81.3 \%$; lactose, $68.6 \%$; apples, $46.9 \%$; potatoes, $41.4 \%$; bread, $36.3 \%$; rice, $33.8 \%$; honey, $32.4 \%$ and carrots, $16.1 \%$.

Key words: Type 2 diabetes, simple and complex carbohydrates, dietary fibre, diabetic diet, honey.
Diet is a basic factor in the treatment of diabetes. Nevertheless, recent controversies concerning the composition of the diet in diabetes have highlighted the relative paucity of experimental data or clinical studies on this subject $[17,20,21,32,33,37]$. A conclusion from some recent studies is the favourable effect of a high dietary fibre intake, which improves tolerance to carbohydrates and ensures a better metabolic control of diabetes $[1,2,6,13,29,30,34,41-43,47]$. It has been shown that similar effects may be obtained by supplementation of the diet with 'purified fibres', such as guar and pectin $[3,14,15,22,23,26]$ or wheat bran [5], although the effects of the latter are not as clear cut. However, these pharmacological supplements make food unpalatable $[7,12,38]$ so that most diabetic patients will not comply [48]. A more physiological approach appears to be that of increasing the fibre intake by consuming foods containing natural fibre $[2,29,30,38,42]$. Such a diet should, however, be based on sound knowledge of the glucose response to different foods. Unfortunately, there are few studies $[9-11,19,27,39]$ and most of them refer to a limited number of foods.

This paper is a comparative study of the blood glucose and insulin responses recorded in a group of Type 2 diabetic patients after the oral administration of three refined carbohydrates (glucose, fructose, lactose) and six different foods (apples, potatoes, rice, bread, honey and carrots).

\section{Patients and Methods}

\section{Patients}

Thirty-two diabetic patients participated in the study following informed consent, being admitted to the Clinic of Nutrition and Metabolic Diseases. The patients ( 21 females and 11 males) ranged in age between 45 and 71 years (mean \pm SEM, $58.4 \pm 0.63$ years). The mean duration of diabetes was $7.1 \pm 0.36$ years and mean index of body mass (weight/height ${ }^{2}$ ) $27.2 \pm 0.32$. Nine diabetic patients were on diet alone, nine were on tolbutamide $(0.5-1 \mathrm{~g} /$ day $)$, six on metformin $(0.5-1 \mathrm{~g} /$ day $)$, and eight on tolbutamide $(0.5-1 \mathrm{~g} /$ day) plus metformin $(0.5-1 \mathrm{~g} /$ day $)$. These patients were considered to be under fairly good metabolic control (blood glucose $<10 \mathrm{mmol} / 1$ determined 1 day before the test).

\section{Methods}

The tests were carried out in hospital over a 10-14 day period, during which time the patients consumed a weight-maintaining diet that included at least $200 \mathrm{~g}$ carbohydrate/day and at least $2200 \mathrm{kcal} /$ day. Oral hypoglycaemic agents and any drug known to influence glucose metabolism were withdrawn 1 day before each test. One test meal 
Table 1. The order of tests carried-out on 32 Type 2 diabetic patients

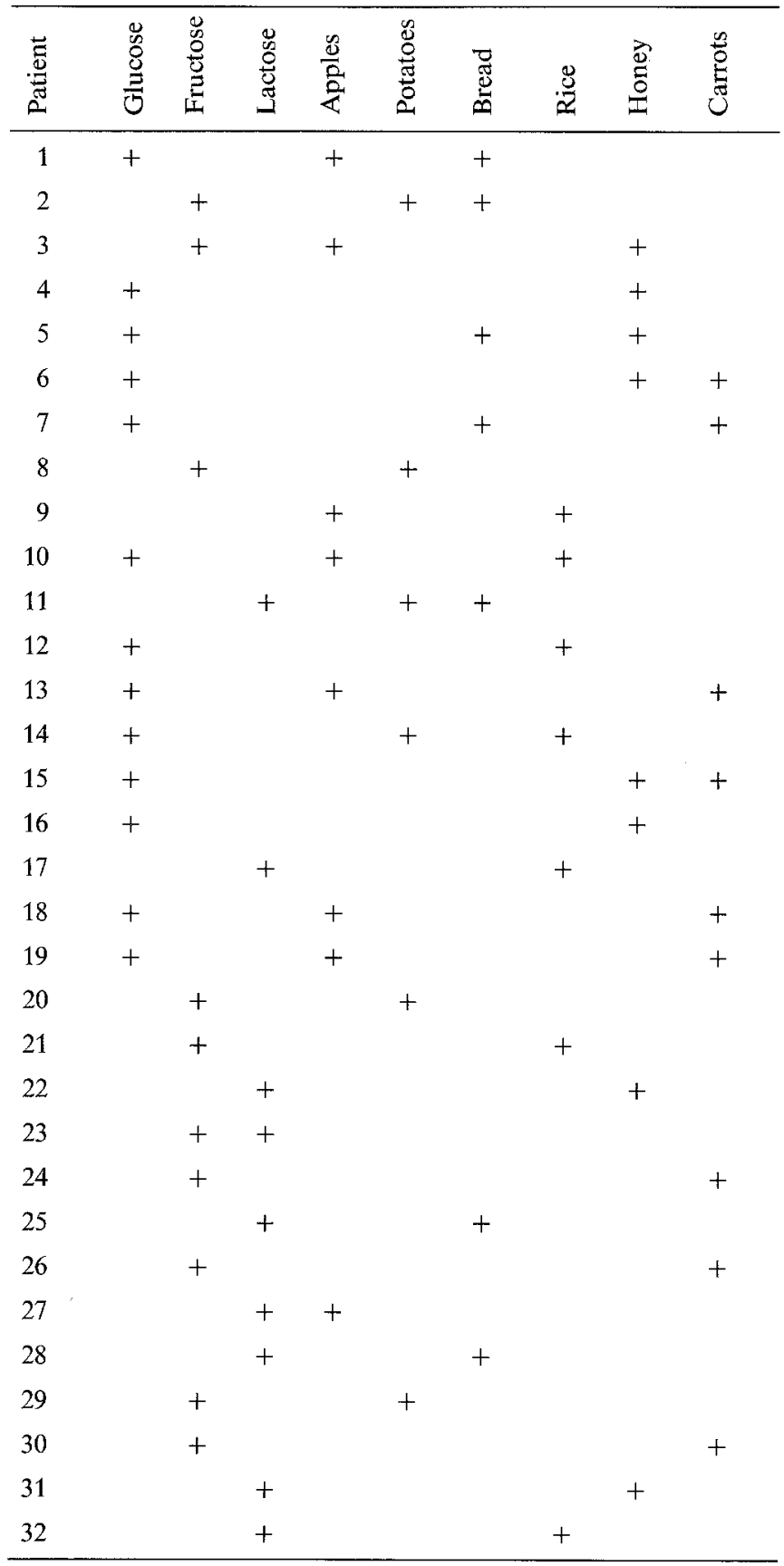

consisted of refined carbohydrate (glucose, fructose or lactose), and the other (s) of the foods mentioned below.

Seventy-seven tests were performed as shown in Table 1. All tests were conducted at $08.00 \mathrm{~h}$ after an overnight fast. The test meals contained $25 \mathrm{~g}$ carbohydrates: $25 \mathrm{~g}$ glucose, fructose or lactose, $30 \mathrm{~g}$ locust honey, $50 \mathrm{~g}$ white bread, $125 \mathrm{~g}$ cooked white rice, $125 \mathrm{~g}$ cooked potatoes, $180 \mathrm{~g}$ apples (14\% carbohydrates) and $260 \mathrm{~g}$ raw carrots $(9.2 \%$ carbohydrates). Carbohydrate amounts in the various test meals were calculated on the basis of up-to-date tables (Romanian Institute for Food Technology, 1980) referring to the nutrient composition of foods. The white rice and potatoes were cooked $1 \mathrm{~h}$ before each study. Each test meal was consumed in 10-15 min. Glucose, fructose, lactose and honey were taken with $100 \mathrm{ml}$ water.

Venous blood samples were drawn for glucose and insulin measurements in the fasting state (zero time) and then at 15, 30,60,90 and 120 min after the beginning of eating. Blood glucose samples were analyzed using the orthotoluidine method and plasma insulin by radioimmunoassay. These methods have been described previously [19]. The results are expressed as mean \pm SEM, and the paired t-test was applied for comparing the data of the different carbohydrates.

\section{Results}

The mean values ( \pm SEM) for blood glucose and plasma insulin, before and after intake of each carbohydrate tested, are presented in Tables 2 and 3. The highest blood glucose values were observed after the three refined carbohydrates, glucose itself giving the greatest increase.

At $60 \mathrm{~min}$ potatoes, bread, rice, apples, honey and carrots, whose available carbohydrate is largely as sugars, gave significantly lower increases in blood glucose $(p<0.01)$ than the refined carbohydrates. Some findings were of interest: apples induced a rapid increase, reaching a peak at $30 \mathrm{~min}$, with return almost to initial values after $2 \mathrm{~h}$; white bread and potatoes gave similar increments at $60 \mathrm{~min}$ (although the proportion of carbohydrate differed significantly, $50 \%$ and $20 \%$, respectively). Two hours later, however, blood glucose was higher after potatoes than after bread. White rice induced an intermediate glucose response, but at $2 \mathrm{~h}$ the values were not significantly higher than when eating commenced. An unexpectedly small increase of glucose (and insulin) was recorded after honey, although this product does not contain dietary fibre and its concen-

Table 2. Blood glucose responses after intake of various simple and complex carbohydrates

\begin{tabular}{|c|c|c|c|c|c|c|c|}
\hline \multicolumn{2}{|c|}{ Carbohydrate } & \multicolumn{6}{|c|}{ Blood glucose response $(\mathrm{mmol} / \mathrm{l})$} \\
\hline Glucose & $(n=13)$ & $9.8 \pm 0.4$ & $11.8 \pm 0.4$ & $15.3 \pm 0.6$ & $16.2 \pm 0.6$ & $13.6 \pm 0.5$ & $11.8 \pm 0.4$ \\
\hline Lactose & $(n=9)$ & $8.9 \pm 0.5$ & $9.7 \pm 0.5$ & $11.2 \pm 0.6$ & $13.5 \pm 0.6$ & $12.3 \pm 0.6$ & $11.1 \pm 0.7$ \\
\hline Apple & $(n=8)$ & $9.4 \pm 0.5$ & $9.8 \pm 0.6$ & $12.3 \pm 0.6$ & $11.3 \pm 0.6$ & $11.2 \pm 0.6$ & $10.7 \pm 0.6$ \\
\hline Potatoes & $(n=6)$ & $9.1 \pm 0.6$ & $9.5 \pm 0.7$ & $10.3 \pm 0.7$ & $11.5 \pm 0.7$ & $11.5 \pm 0.7$ & $10.8 \pm 0.6$ \\
\hline Honey & $(n=8)$ & $9.1 \pm 0.6$ & $10.1 \pm 0.6$ & $10.9 \pm 0.6$ & $11.1 \pm 0.7$ & $10.1 \pm 0.6$ & $9.7 \pm 0.6$ \\
\hline Carrot & $(n=9)$ & $8.8 \pm 0.5$ & $9.2 \pm 0.5$ & $9.8 \pm 0.5$ & $10.0 \pm 0.5$ & $9.2 \pm 0.5$ & $9.1 \pm 0.5$ \\
\hline
\end{tabular}

Results expressed as mean \pm SEM 
Table 3. Plasma insulin responses after intake of various simple and complex carbohydrates

\begin{tabular}{|c|c|c|c|c|c|c|c|}
\hline \multicolumn{2}{|c|}{ Carbohydrate } & \multicolumn{6}{|c|}{ Plasma insulin response (mU/1) } \\
\hline Glucose & $(n=13)$ & $12.8 \pm 0.5$ & $37.6 \pm 0.6$ & $60.5 \pm 0.9$ & $53.3 \pm 0.9$ & $26.6 \pm 0.8$ & $18.4 \pm 0.7$ \\
\hline Lactose & $(n=9)$ & $14.2 \pm 0.6$ & $17.8 \pm 0.7$ & $20.5 \pm 0.9$ & $25.3 \pm 0.8$ & $25.3 \pm 0.9$ & $17.3 \pm 0.8$ \\
\hline Apple & $(n=8)$ & $13.1 \pm 0.8$ & $20.7 \pm 0.8$ & $39.6 \pm 1.1$ & $40.6 \pm 1.0$ & $25.6 \pm 0.7$ & $17.7 \pm 0.8$ \\
\hline Potatoes & $(n=6)$ & $12.8 \pm 0.8$ & $18.5 \pm 1.0$ & $38.3 \pm 1.2$ & $39.2 \pm 1.2$ & $22.4 \pm 1.1$ & $19.4 \pm 1.0$ \\
\hline Honey & $(n=8)$ & $14.1 \pm 0.7$ & $16.4 \pm 0.8$ & $19.3 \pm 0.8$ & $21.3 \pm 0.8$ & $17.7 \pm 0.8$ & $15.6 \pm 0.9$ \\
\hline Carrot & $(n=9)$ & $13.7 \pm 0.7$ & $15.9 \pm 0.6$ & $18.0 \pm 0.7$ & $19.2 \pm 0.7$ & $18.6 \pm 0.7$ & $14.8 \pm 0.8$ \\
\hline
\end{tabular}

Results expressed as mean \pm SEM

tration of carbohydrates is very high ( $80 \%$ of entire product). Finally, carrots, with the lowest carbohydrate content $(9.2 \%)$, gave the lowest blood glucose increase.

Figure 1 shows the glucose response to carbohydrates, expressed as the sum of the blood glucose increments above baseline at 15, 30, 60, 90 and $120 \mathrm{~min}$. Taking the response after glucose as $100 \%$, that after fructose was $81.3 \%$, after lactose $68.6 \%$, apples $46.9 \%$, potatoes $41.4 \%$, bread $36.3 \%$, rice $33.8 \%$, honey $32.8 \%$ and carrots $16.1 \%$.

In general, the insulin response (Table 3) ran in parallel with the blood glucose increase within the first 15-30 min: the greater the increment in blood glucose, the greater was the plasma insulin response.

\section{Discussion}

As expected, the highest blood glucose increase was recorded after the more refined carbohydrates, being significantly lower after fructose and lactose than after glucose itself $(p<0.01)$. A shift of the blood glucose curve to the right after fructose and lactose may be explained by the intervention of an intermediate stage during their transformation into glucose $[31,35]$. As already mentioned by others $[4,31]$ the plasma insulin response after fructose (or lactose) is much lower than that after glucose.

As amounts of carbohydrate were approximately equal $(25 \mathrm{~g})$ in all the test meals, the different glucose responses recorded were surprising. Differences for some foods have already been emphasized by several workers $[9-11,27,28,39,44,45]$. In general, for foods that induced a more rapid and greater increase (apples and bread), the values recorded at $2 \mathrm{~h}$ were lower. This decrease is brought about by the plasma insulin response running parallel to the increase in blood glucose. The slower absorption of rice and potato carbohydrates, expressed in the right shift of the curve plotted, might perhaps explain the high values found $2 \mathrm{~h}$ after ingestion of this food.

An expectedly low blood glucose increase was recorded after the consumption of carrots and honey. For

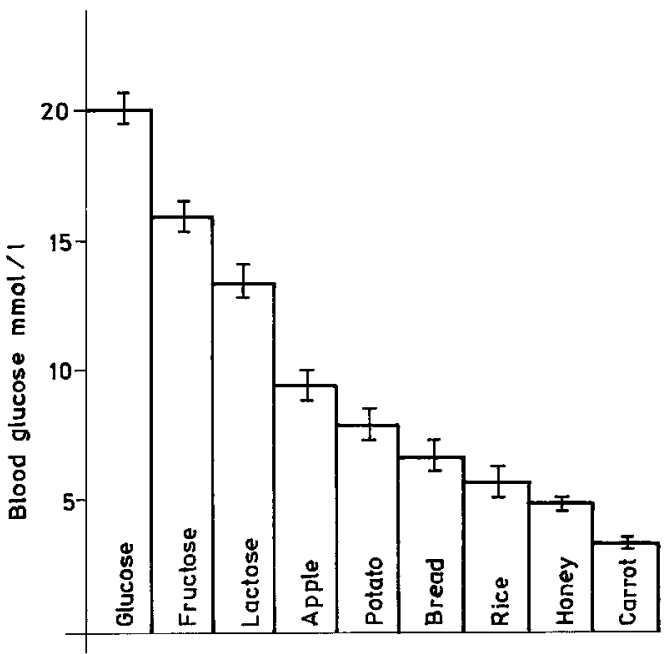

Fig. 1. Sum of blood glucose increase at $15,30,60,90$ and $120 \mathrm{~min}$ over initial value after $25-\mathrm{g}$ intake of several carbohydrates. Statistics: glucose $>$ fructose $(p<0.02)$; glucose $>$ lactose, apple, potato, bread, rice, honey and carrot $(p<0.01)$; fructose $>$ apple, potato, bread, rice, honey and carrot $(p<0.01)$; fructose-lactose NS; lactose $>$ apples $(p<0.05)$, potato $(p<0.02)$, bread, rice, honey, carrot $(p<$ $0.01)$; apples $>$ rice $(p<0.05)$, honey $(p<0.02)$, carrot $(p<0.01)$; apple-potato and apple-bread NS; potato honey $(p<0.02)$, carrot $(p<0.01)$; potato-bread and potato-rice NS; bread $>$ carrot $(p<0.01)$; bread-rice and bread-honey NS; rice $>$ carrot $(p<0.01)$; rice-honey NS; honey $>\operatorname{carrot}(p<0.01)$

carrots, this may be explained by their high content of dietary fibre. For honey, as previously reported [19], the high fructose content cannot be expected to raise blood glucose as much as glucose itself [27]. Apart from carbohydrates (approximately 80\%, especially fructose) honey also contains some protein compounds (amino-acids, enzymes, hormones), vitamins and trace elements. The metabolic effects of those have not yet been fully established; it is possible that they may include a hypoglycaemic factor.

The hyperglycaemic effects recorded after food of plant origin depend on the rapidity of gastric voiding [18], as well as on rates of digestion and absorption [26]. Several factors connected with dietary fibre have been implicated: amount $[1,2,14,34]$, origin $[10,24,46,48]$, 
physical integrity $[16,36,40]$, or homogenization of the processed product when added in the form of guar gum or pectin $[22,24,25]$. Although dietary fibre is an important element in the prevention of a marked increase in blood glucose, it cannot explain the variations observed in glucose response to meals having an equal fibre content, unless different fibres have different effects as indeed appears to be the case. Here the presence in natural vegetable products of certain bioactive substances' may be important, including: plant pigments (carotenoids, flavones, quinones), enzymes, phytohormones, glycosides, alkaloids etc.

Concerning the hyperglycaemic effect of foods, high post-prandial blood glucose levels can be avoided by a daily intake of $300 \mathrm{~g}$ of slowly absorbed carbohydrates; conversely, high levels may appear when the diet contains only $150 \mathrm{~g}$ rapid absorption carbohydrates.

In order to prescribe a diet containing an appreciable amount of carbohydrate, without inducing a high parallel increase in blood glucose (with its deleterious effects), grading of the different foods in terms of the glycaemic response, as has been done for normal individuals [27], may be very useful.

Acknowledgements. We wish to express our gratitude to I. Sturza for expert technical assistance, to M.Zenaida for plasma insulin determinations and to M. Fachler for blood glucose determinations.

\section{References}

1. Anderson JW (1977) Effect of carbohydrate restriction and high carbohydrate diets on men with chemical diabetes. Am J Clin Nutr 30: 402-408

2. Anderson JW, Karonnos D (1978) Beneficial effects of high carbohydrate, high fiber diets for insulin-treated diabetic men. Diabetes 27 (Suppl 2): 443 (Abstract)

3. Aro A, Uusitupa M, Vontilainen E, Hersio K, Korhonen T, Siitonen $O$ (1981) Improved diabetic control and hypocholesterolemic effect induced by long-term dietary supplementation with guar gum in Type 2 (insulin-independent) diabetes. Diabetologia 21: $29-33$

4. Bohannon NV, Karam JH, Forahem PH (1978) Advantages of fructose ingestion over sucrose and glucose in humans. Diabetes 27 (Suppl 2): 483-487

5. Bosello O, Ostuzzi R, Armellini F, Micciolo RM, Ludovico AS (1980) Glucose tolerance and blood lipids in bran fed patients with impaired glucose tolerance. Diabetes Care 3: 46-49

6. Brunzell JD, Lerner RL, Porte D, Bierman EL (1971) Improved glucose tolerance with high carbohydrate feeding in mild diabetes. N Engl J Med 284: 521-524

7. Cohen M, Martin FR (1979) Guar crispbread in the diabetic diet. Br Med J 2: 616-617

8. Collings P, Williams C, MacDonald I (1981) Effect of cooking on serum glucose and insulin responses to starch. Br Med J 282: 1032-1036

9. Crapo PA, Reaven G, Olefsky J (1976) Plasma glucose and insulin responses to orally administered simple and complex carbohydrates. Diabetes 25: 741-747

10. Crapo PA, Kolterman OG, Waldek N, Reaven GM, Olefsky JM (1980) Postprandial hormonal responses to different types of complex carbohydrates in individuals with impaired glucose tolerance. Am J Clin Nutr 33: 1723-1728

11. Cristacopoulos PD, Karamanos BG, Zachariou NZ, Tountas CD, Komninos ZD (1980) Different insulin and blood glucose levels after administration of equal amounts of carbohydrates contained in different foodstuffs. Diabetologia 19:264 (Abstract)

12. Dewar J, Garcia WP, Shenfield GM (1979) Guar and diabetes. Lancet 1: 612 (Letter)

13. Douglas JM (1975) Raw diet and insulin requirements. Ann Intern Med 82: 61-65

14. Goulder TJ, Alberti KGMM (1978) Dietary fibre and diabetes. Diabetologia 15: 285-287

15. Goulder TJ (1979) Guar and diabetes. Lancet 1: 612 (Letter)

16. Haber GB, Heaton KW, Murphy D, Burroughs LF (1977) Depletion and disruption of dietary fibre. Effects on satiety, plasmaglucose, and serum insulin. Lancet 2: 679-682

17. High-fibre diets and diabetes (Editorial) (1981) Lancet 1:423

18. Holt S, Carter D, Heeding R, Prescott L, Tothill P (1979) Effect of gel fibre on gastric emptying and absorption of glucose and paracetamol. Lancet 1: 636-639

19. Ionescu-Tîrgovişte C, Sîntu E, Mihalache N, Cheţa D, Boboia D, Constantinescu A, Fachler E, Sgarbură M (1979) The hyperglycaemic effect of some concentrated carbohydrates in non-insulin dependent diabetics. Acta Diabetol Romana 5: 54-61

20. Jarret RJ (1981) How much carbohydrate? Diabetologia 20: 507 (Letter)

21. Jarrett RJ (1981) More about carbohydrates. Diabetologia 21: 427-428 (Letter)

22. Jenkins DJA, Leeds AR, Gassull MA, Cochet BJ, Alberti KGMM (1977) Decrease in postprandial insulin and glucose concentrations by guar and pectin. Ann Intern Med 86: 20-25

23. Jenkins DJA, Wolever TMS, Ninehan R, Taylao R, Metz LG, Bacon S, Hockaday TDR (1978) Guar crispbread in the diabetic diet. Br Med J 2: 1744-1746

24. Jenkins DAJ, Wolever TMS, Leeds AR, Gassull MA, Dilawari JB, Goff DV, Metz GL, Alberti GKMM (1978) Dietary fibres, fibre analogues and glucose tolerance: importance of viscosity. Br Med J 1: 1392-1394

25. Jenkins DJA, Nineham R, Craddock C, Craig-McFeely P, Donaldson K, Leigh T, Snook J (1979) Fibre and diabetes. Lancet 1: 434435

26. Jenkins DJA, Wolever TSM, Taylor RH, Ghafary H, Jenkins AL, Barker H, Jenkins MJA (1980) Rate of digestion of foods and postprandial glycaemia in normal and diabetic subjects. Br Med $\mathbf{J}$ 2: 14-17

27. Jenkins DJA, Wolever TMS, Taylor RH, Barker HN, Fielden $H$, Baldwin JM, Bowling AC, Newman HC, Jenkins AL, Goff DV (1981) Glycemic index of foods: a physiological basis for carbohydrate exchange. Am J Clin Nutr 34: 362-366

28. Karlander SG, Andersen E, Kindstedt K, Helleström K (1980) Effects of two sources of starch on glucose and insulin levels in Type 2 diabetic patients. Diabetologia 19:287 (Abstract)

29. Kay RM, Grobin W, Trach NS (1981) Diets rich in natural fibre improve carbohydrate tolerance in maturity-onset, non-insulin dependent diabetics. Diabetologia 20: 18-21

30. Kiehm TG, Anderson JW, Ward K (1976) Beneficial effect of a high carbohydrate diet on hyperglycemic diabetic men. Am J Clin Nutr 29: 895-899

31. MacDonald I, Keyser A, Pacy D (1978) Some effects, in men, of varying the load of glucose, sucrose, fructose, or sorbitol on various metabolites in blood. Am J Clin Nutr 31: 1305-1311

32. Mann JI, Simpson HCR (1980) Dietary management of maturityonset diabetes. Br Med J 2: 62 (Letter)

33. Mann JI, Kinmonth AL, Todd E, Angus RM, Simpson HCR, Hockaday TDR (1981) High fibre diets and diabetes. Lancet 1: 731 (Letter)

34. Miranda PJ, Horwitz DL (1978) High-fibre diets in the treatment of diabetes mellitus. Ann Intern Med 88: 482-486

35. Miller M, Dreker WR, Owens JE, Craig JW, Woodward H (1962) Metabolism of intravenous fructose and glucose in normal and diabetic subjects. J Clin Invest 31: 115-125

36. O'Dea K, Nestel PJ, Antonoff L (1980) Physical factors influencing postprandial glucose and insulin response to starch. Am J Clin Nutr 33: 760-765 
37. Reaven GM (1980) How much carbohydrate? Diabetologia 19: 409-413

38. Rivelese A, Riccardo G, Giacco A, Pacioni D, Genovese S, Mattioli PL, Mancini M (1980) Effect of dietary fibre on glucose control and serum lipoproteins in diabetic patients. Lancet 2: 447-450

39. Schauberger G, Brinck UC, Suldner G, Spaethe R, Niklas L, Otto $H$ (1978) Exchange of carbohydrates according to their effect on blood glucose. Diabetes 26: 415-417

40. Schusdziarra V, Dangel G, Kelir M, Henrrich J, Pfeiffer EF (1981) Effect of solid and liquid carbohydrates upon postprandial pancreatic endocrine function. J Clin Endocrinol Metab 53: 16-20

41. Simpson RW, Mann JI, Eaton J (1979) High-carbohydrate diets and insulin dependent diabetics. Br Med J 2: 523-525

42. Simpson RW, Mann JI, Eaton J, Moore RA, Carter R, Hockaday TDR (1979) Improved glucose control in maturity onset diabetes treated with high carbohydrate-modified fat diet. $\mathrm{Br}$ Med $\mathrm{J} 1$ : 1753-1756

43. Simpson HCR, Simpson RW, Lousley S, Carter RD, Geekie M, Hochaday TDR, Mann JI (1981) A high carbohydrate leguminous fibre diet improves all aspects of diabetic control. Lancet 1:1-5

44. Spaethe R, Brinck UC, Sabin J, Wubbens D, Otto H (1972) Echanges des hydrates de carbone d'après le principe des équivalences biologiques dans le régime pour diabétiques. In: Journées
Annuelles de Diabétologie Hôtel-Dieu. Ed. Flammarion, Paris, pp 253-259

45. Uzzan M (1971) Note sur la répartition des diverses glucydes dans la ration alimentaire des diabétiques. Cahiers Nutr Diét 6: 61-63

46. Vaaler $S$, Hanssen KF, Aagenaes $\emptyset$ (1979) Influence of different kinds of dietary fibre on blood glucose responses after a carbohydrate-rich meal in juvenile diabetics. Excerpta Med Int Congress Series 481-241 (Abstract)

47. Weinsier RL, Seeman A, Herrera MG, Assal JP, Soeldner JS, Gleasson RE (1974) High and low carbohydrate diets in diabetes mellitus. Study of effects on diabetic control, insulin secretion and blood lipids. Ann Intern Med 80: 332-341

48. Williams DRP, James WPT (1979) Guar and diabetes. Lancet 1: 612-613

Received: 11 January 1982

and in revised form: 6 September 1982

Dr. C. Ionescu-Tîrgoviste

Clinic of Nutrition and Metabolic Diseases

I. Movila 5-7

70266 Bucharest 2

Romania 